\title{
ECONOMETRIC ESTIMATION OF ARMINGTON IMPORT ELASTICITIES FOR A REGIONAL CGE MODEL OF THE ILLINOIS ECONOMY
}

\author{
KAREN TURNER ${ }^{\mathrm{a}^{*}}$, SOO JUNG HA ${ }^{\mathrm{b}}$, GEOFFREY J.D. HEWINGS ${ }^{\mathrm{c}}$, PETER MCGREGOR $^{\mathrm{d}}$ \\ and KIM SWALES ${ }^{\mathrm{d}}$ \\ ${ }^{a}$ University of Stirling, UK $;{ }^{b}$ Korean Research Institute for Human Settlements, Seoul, Republic of \\ Korea; ${ }^{c}$ University of Illinois, Urbana-Champaign, USA; ${ }^{d}$ University of Strathclyde, Glasgow, \\ $U K$
}

(Received 9 December 2010; In final form 12 April 2011)

One of the main concerns associated with the development and use of regional CGE models is the determination of key parameter values, particularly substitution and other price elasticities. A common problem is the lack of appropriate regional data for econometric estimation. Consequently, it is important to identify key parameters that are likely to be important in determining quantitative results and then to prioritize these for estimation where appropriate data are available. In this paper, the focus is on the estimation of the regional trade (import) substitution parameters, which tend to be important in analys is for regional economies (given their openness to trade). Here, commodity import elasticities for the Illinois economy are estimated and tested in a single region CGE model of the Illinois economy. In our econome tric estimation, we apply a model that takes account of market size and distance in estimating the substitutability between commodities produced in Illinois and other US states.

Keywords: CGE models; Input-output tables; parameter estimates; regional mode ling; Armington import elasticities 


\section{Introduction}

Many variations of computable general equilibrium (CGE) models of the U.S. national economy have demonstrated the value of the approach in assessing the potential long-run effects of government policies, impacts of environmental actions as well as the effects of proposed and enacted free trade agreements. At the regional level, the analyses of those effects within countries have been more limited and problematic (Partridge and Rickman, 1998, 2010; Holland, 2010). A likely reason for the lack of regional CGE studies (examples include Dixon et al, 2007; Hoffmann et al., 2006; Seung et al., 2010) is that the necessary regional data in a suitable form are often not available. Moreover, a number of unresolved behavioral issues remain, including the extent of interregional factor mobility and the uniqueness of regional goods. As a result, the level of uncertainty and the magnitude of errors in regional CGE models may be higher than those in nationallevel models.

For example, although elasticities of import substitution have been extensively estimated for U.S. trade (Stern et al., 1976; Shiells et al., 1986; Shiells and Reinert, 1993), limited information is available for elasticities of substitution for regional imports. Therefore, regional CGE modelers often use elasticities estimated for national commodity or industry classifications that may not be consistent with those maintained in the model, outdated estimates from past literature, or only 'best guesses' when no published figures are available (for a review, see Partridge and Rickman, 1998, 2008). However, if parameters are specified without representing regional characteristics, any simulation results are likely to be inaccurate.

Recognizing this problem, CGE analysts have directed attention to the issue of uncertainty and error of behavioral parameters and many researchers have tested the uncertainty and errors surrounding these parameters in terms of their impact on the model (e.g. Hertel, 1985; Harrison and Vinod, 1992; Harrison et al., 1993; DeVuyst and Preckel, 1997). Such sensitivity analyses are considered as an important step in the application of CGE models to evaluate the variability of results of simulating policy and other disturbances to model specification.

Generally, knowledge of key parameters is important for CGE analysis of a small 
open economy because of the degree to which a policy change that will affect key macroeconomic variables will depend on the magnitude of key price elasticities and other parameters adopted in the model. Here, we focus on the estimation of regional trade (import) substitution parameters for the Illino is economy. These parameters are generally important in analysis for regional economies, which tend to be more ope n than national economies. Specifically, we estimate commodity import elasticities for the case of Illinois and the rest of the US (RUS). A model is applied where account is taken of market size and distance in estimating the substitutability between commodities produced in Illinois and other US states.

The remainder of the paper is organized as follows. Section 2 provides theoretical background for the regional import elasticity estimates. Section 3 explains the analytical model and data, with results of the parameter estimation following in section 4. Section 5 introduces the Illinois CGE model and tests the impact of introducing the estimated parameter values. Section 6 provides conclusions.

\section{Regional import elasticities - theoretical background}

Regional economic policy can affect the price of traded goods relative to domestically produced goods. For example, tax and subsidy policy or any type of government regulation that affects the behavior of firms or consumers may influence trade between regions. Even though differentiation by government agencies at the regional level may not be as pronounced as at the national level, at the margin, the differences may turn out to be important. The "cost of doing business" is often highlighted as an important discriminator in the choice of location by many firms. Furthermore, processes of fragmentation and hollowing out and changes in the nature of regional specialization have combined to generate increased interregional trade at the expense of intraregional trade (see Hewings and Parr, 2009; Romero et al., 2009). As a result, a key relationship for regional CGE analysis is the degree of substitution between intraregional and interregional traded goods, commonly identified as the Armington price elasticity (Armington, 1969). Commodities produced at different locations are seldom perfect 
substitutes. Because of real or apparent differences, discriminating buyers evaluate their willingness to substitute between imports and domestic goods within comparable product categories. Thus, there exists a potential for price differences between locally produced and imported products from comparable product categories (Reinert and Roland-Holst, 1992). The factors determining the different price of goods are various: the demand for consumption and industrial inputs, the supply of production (labor costs, costs of materials), and technological progress in the transportation sector as well as improvements in the efficiency of transactions.

The hypothetical representative consumer (be they an intermediate or final consumer) minimizes costs or maximizes utility from a composite $(Q)$ of imported $(M)$ and domestic $(D)$ goods, and it is assumed there are continuous substitution possibilities between the two options. The individual consumer's decision problem is to choose a mix of $M$ and $D$ that minimizes expenditure, given respective prices $p_{m}$ and $p_{d}$ and the desired level of $Q$. In other words, consumers purchase quantities of domestic versus imported goods depending on their willingness to substitute and the ratio of the two prices. In the Armington specification, a CES functional form is chosen for $Q$ :

$Q=\alpha\left[\beta M^{(\sigma-1) / \sigma}+(1-\beta) D^{(\sigma-1) / \sigma}\right]^{\sigma /(\sigma-1)}$

where $\alpha$ and $\beta$ are calibrated parameters and $\sigma$ is the elasticity of substitution between imports and domestic goods. The solution to the consumer's optimization problem will be to choose imports and domestic goods whose ratio satisfies the first-order condition:

$M / D=\left[(\beta /(1-\beta))\left(p_{D} / p_{M}\right)\right]^{\sigma}$

which is the familiar equivalence between rates of substitution and relative prices. The parameter $\sigma$ also can be interpreted as the compensated price elasticity of import demand. Commodity-level estimates of Armington elasticities for the US have appeared over the last few decades. For example, Stern et al. (1976) estimate US imports-demand elasticities for 28 commodities produced by industries identified at the three-digit SIC level and divide them into three categories, extremely import sensitive, moderately 
import sensitive, and import inelastic. Shiells and Reinert (1993) use quarterly data over the period 1980-1988 and obtain estimates for 128 mining and manufacturing sector outputs. One of the most widely cited studies in the literature, Reinert and Roland-Holst (1992) estimate Armington elasticities for 163 U.S. mining and manufacturing commodities using quarterly data from 1980 to 1988 .

Application of the Armington assumption has mainly been at the international or country level because of the data limitation of commodity trade among regions. However, the U.S. Census Bureau, U.S. Department of Commerce, and the Bureau of Transportation Statistics have undertaken the Commodity Flow Survey (CFS). This survey produces interstate commodity flow data for the United States. It provides information on commodities shipped, their value, weight, and mode of transportation, as well as the origin and destination of shipments of selected manufacturing, mining, wholesale, and retail establishments. However, the data only cover physical commodities and no differentiation is made between intermediate and final demand flows. Further, commodity trade among states within the same country may also reflect quality differences among products or just the variety of consumption preferences. Differences in product mixes within the same category produced at each location may also provide an explanation for observation of imports and exports of the same category of goods. This has led to the common use of the uniform Constant Elasticity of Substitution (CES) class of function, in which a single nonnegative substitution elasticity is imposed across all pairs of factors.

\section{Econometric model and data}

To estimate regional import elasticities for Illinois, data are selected from published information on 2002 commodity flows data (Bureau of Transportation Statistics, 2005) Although a number of trade models have been developed, the CES structure is relatively easy to explain and estimate so that the analytical specification follows Bilgic et al. (2002) and Erkel-Rousse and Mirza (2002). For the first specification, a CES function is adopted to represent the direct commodity satisfaction (utility) index, which applies to all 
consumers, intermediate or final (data are not available to estimate for different consumers individually):

$U_{I L k}=\left(\sum_{j} \beta_{I L k} X_{I L j k}^{\rho}\right)=\sum\left(\beta_{1 k} X_{I L k}^{\rho}+\beta_{2 k} X_{j k}^{\rho}\right)$

where $j=1, \ldots r$ for region (state); $k=1, \ldots n$ for commodity group; $\beta_{1 k}+\beta_{2 k}=1 ; \rho$ is a substitution parameter; $X_{I L k}$ refers to (total) intraregional commodity consumption of Illinois for commodity $k$; and $X_{j k}$ refers to (total) interregional commodity consumption by Illinois from other states $j$ for commodity $k$. The CES is linear in parameters, and thus more easily estimated (Chung, 1994).

Maximizing Equation 3 subject to the total expenditure constraint yields:

$M_{I L k}=\sum_{j} P_{I L i j k} X_{I L j k}$

and produces a system of demands that estimates intraregional and interregional consumption:

$$
\left[\frac{x_{I L k}}{x_{j k}}\right]=m^{\sigma}\left[\frac{p_{j k}}{p_{I L k}}\right]^{\sigma}
$$

where $m=\left[\beta_{1 k} / \beta_{2 k}\right], \quad \sigma=[1 /(1-\rho)]$ is the elasticity of substitution; $p_{I L k}=[$ Illinois intraregional commodity $k$ value (\$ millions) /Illinois intraregional commodity $k$ weights (thousand ton) $]^{*} 1000$ is the unit price for Illinois and $k^{\text {th }}$ commodity intraregional consumption; $P_{j k}=$ [Interregional commodity $k$ value $(\$$ millions $)$ /Interregional commodity $k$ weights (thousand ton) $]^{*} 1000$ is the unit price for interregional consumption from the $j^{\text {th }}$ region and $k^{\text {th }}$ commodity. $m$ is then defined as depending on states' characteristics defined as $Q_{j k}$ and $d_{I L j}$, which represent market size and distance 
factor, respectively, and $\delta_{s}$ is the set of parameters associated with state $j$ characteristics. ${ }^{1}$

$m=\left[\frac{\beta_{1 k}}{\beta_{2 k}}\right]=\exp \left(\delta_{0}+\delta_{1} \ln Q_{j k}+\delta_{2} \ln d_{I L j}\right)$

The market size factor is included as an explanatory variable to capture the share of the amount of intraregional demand to interregional demand (larger markets are able to support more production and thus imports from larger market increase relative to intraregional goods). The market size variable is measured as the proportion of Illinois gross state product to the other region's gross state product by each industry sector. Owing to the potentially important influence of spatial effects, the distance factor is included in the price expression in order to indicate that the closer the state is located to Illinois, the more likely the volume of interregional goods increases. Distance is calculated as the centroid distance between Illinois and the other 49 states.

Taking natural logs of both sides of Equation 5 yields

$\ln \left[\frac{X_{I L k}}{X_{j k}}\right]=\sigma \ln m+\sigma \ln \left[\frac{P_{j k}}{P_{I L k}}\right]$

Substituting for the term $m$ defined by Equation 6 into Equation 7 produces

$\ln \left[\frac{X_{I L k}}{X_{j k}}\right]=\left[\alpha_{0}+\alpha_{1} \ln Q_{j k}+\alpha_{2} \ln d_{I L j}\right]+\sigma \ln \left[\frac{P_{j k}}{P_{I L k}}\right]$

where $\alpha_{0}=\sigma \delta_{0}, \alpha_{1}=\sigma \delta_{1}, \alpha_{2}=\sigma \delta_{2}, \ln \left\lfloor P_{j k} / P_{I L k}\right\rfloor$ is the natural $\log$ of the price ratio for interregional goods to intraregional goods.

The estimated parameters capture the effects of market size and distance as well as the

\footnotetext{
${ }^{1}$ More details on the derivation of market size and distance factors may be found in Erkel-Rousse and Mirza (2002).
} 
constant term. The left hand side of Equation 8 is the natural $\log$ of the ratio of the demand for intraregional consumption to the demand for interregional consumption.

In addition to Equation 8, which we will label Estimation Model 1, another testable specification is considered. A weighted distance has been applied using the same calculation method (Head and Mayer, 2000) for Illinois and the rest of states in U.S in order to give a more economically meaningful consideration of distance. Let the weighted distances be expressed as follows:

$w d_{I L j}=s_{I L} s_{j} d_{I L j}$

where $s_{I L}$ is population weight of Illinois in all states, $s_{j}$ is employment weight of state $j$ in all states and $d_{I L J}$ is the centroid distance between Illinois and state $j$ (as in Model 1). As the earlier centroid distance between Illinois and other states in Equation 8 is replaced with a weighted distance expressed as Equation 9, another specification is proposed (which we will label Estimation Model 2):

$\ln \left[\frac{X_{I L k}}{X_{j k}}\right]=\alpha_{0}+\alpha_{1} \ln Q_{j k}+\alpha_{2} \ln w d_{I L j}+\sigma \ln \frac{P_{j k}}{P_{I L k}}$

where $\alpha_{0}=\sigma \delta_{0}, \alpha_{1}=\sigma \delta_{1}$, and $\alpha_{2}=\sigma \delta_{2}$.

Based on the 2002 Commodity Flow Survey (Bureau of Transportation Statistics, 2005), the intraregional and interregional quantity and price variables are computed. The survey provides information on commodities shipped, their value, and weight as well as the origin state and destination state of shipments of manufacturing, mining, wholesale, and select retail establishments. The commodities shown in the CFS are classified by the Standard Classification of Transported Goods (SCTG) coding system that does not cover some industry/commodity categories such as government and retail activities captured in the CGE model (where both the domestic use and import use matrices are given in terms of ind ustries/production sectors, under the assumption that one sector in Illinois and other US regions produces a single commodity). We are able to map 43 commodities by SCTG 
in CFS to 11 sectors among the 24 production sectors in the Illinois CGE model, with greater detail within some of these sectors possible (see Appendix 1 for the sector/commodity breakdown identified in the Illinois CGE model - estimates are made for commodities 1-4 and 9-15, with more detailed breakdown in the case of commodity 12, 14 and 15, but with aggregation across 2-4 in the estimation). Elasticities are not estimated for the remaining 13 commodities produced by the sectors identified in the CGE model. Annual wage data for each state are extracted from Quarterly Census of Employment and Wages (QCEW/ES-202) Data Files from the Bureau of Labor Statistics. Gross State Product and employment data for each state are derived from the REIS (Regional Economic Information System) data set from the Bureau of Economic Analysis.

\section{Econometric Results}

Tables 1 and 2 summarize the results of ordinary least squares estimation of Equation 8 and 10, or Estimation Models 1 and 2, respectively. All estimated elasticities are statistically significant at the 10 percent or lower probability level in the results of estimating Equation 8. For Equation 10, only the estimated elasticity for Textile, Apparel, and Leather Product Manufacturing is not statistically significant at the 10 percent level. The estimations for Estimation Model 1 present interregional price elasticities that range from 0.068 for Textile, Apparel, and Leather Product Manufacturing to 1.517 for Transportation Equipment. For nine out of the thirteen commodities in Tables 1 and 2 the estimations derived from Estimation Model 2 are higher than those resulting from Estimation Model 1. In Table 2, the elasticity estimates range from 0.186 for Medical, Precision and Optical Instruments to 2.169 for Non-Metallic Mineral Products. Four commodities are associated with import elasticities that are higher than unity in Model 1. This rises to six in Model 2 (where the estimate for Non-Metallic Mineral products rises from 1.357 in Model 1 to 2.169 in Model 2 and the estimates for Primary Metal and Metal Product Manufacturing and Miscellaneous Manufacturing rise above 1).

<<Insert Tables 1 and 2 around here>> 
However, examination of the R-squared statistics in the final column of each table suggests that estimation of Equation 8 (Estimation Model 1) produces a much better fit with the data, with all but two (Food, Beverage and Tobacco Products Manufacturing and Wood Products and Furniture) above 0.9. The R-squared statistics for the estimations of Equation 10 (Estimation Model 2) have a much wider range, from 0.41 (Food, Beverage and Tobacco Products Manufacturing and Wood Products and Furniture) up to NonMetallic Mineral Products (0.953), which is the only value above 0.9.

The coefficient for market size is statistically significant at the 10 percent probability level and positive. The interpretation of this elasticity is that market size is positively related to the ratio of intrare gional to interre gional goods demand, which suggests that the share of intraregional goods increases relative to interregional goods if total gross state product in terms of production of the $k^{\text {th }}$ commodity in Illinois is larger. However, it should be noted that those commodities with relatively low price elasticities tend to have higher coefficients of market size. This may imply that market size is correlated with Illino is' capability to provide more intraregional goods relative to interregional goods in the case of commodities that have relatively lower price elasticities: for example, Agriculture, Forestry, Fishing \& Hunting; Textile, Apparel, and Leather Product Manufacturing; and Medical, Precision and Optical Instruments.

The coefficient for the distance factor is statistically significant and positive for all but one of the commodities in Table 1 (Estimation Model 1). For the coefficient for the weighted distance factor, Table 2 shows that the result is statistically significant and positive for eight commodities. This result generally suggests that the closer the trading region or the lower the transport cost, the more interregional goods trade. In both estimations, the coefficient on the distance or transport cost is lower than the price elasticities in Food, Beverage, and Tobacco Product Manufacturing and Transportation Equipment. From this result, it could be inferred that these two commodities tend to be more affected by price differences in the Illinois case, although distance or transport cost effects do exist.

When comparing the price elasticities between commodities, Transportation Equipment (1.517 in Table 1 and 1.905 in Table 2), Non-Metallic Mineral Products 
(1.375 and 2.169), Food, Beverage, and Tobacco Product Manufacturing (1.282 and 1.093), and Machinery and Electric Equipment (1.012 and 1.336) all have large price elasticities of interregional commodity trade relative to other commodities. This indicates that price differences between intraregional goods and interregional goods in Illinois are relatively important for these commodities as compared to commodities that have lower elasticities. Furthermore (see Table 3), the elasticities for these four commodities seem to be higher than the range of elasticities estimated for the same commodities in other US studies which focus on international trade (i.e. national level estimates)and also the those of Bilgic et al. (2002), which focuses on US interstate trade overall (rather than for individual states).

\section{$<$ Insert Table 3 about here $>>$}

On the other hand, Table 3 shows that our estimates for the other nine commodities tend to be lower than those estimated in the other studies for trade at the national level (i.e. international trade). Moreover, they tend to be lower or at the low end of ranges over commodities that US interstate trade elasticities are estimated by Bilgic et al. (2002). This would seem to reinforce the conclusion drawn by Bilgic et al that international trade elasticities should not be used as the lower bounds for regional trade elasticities for comparable goods, particularly where regional specialization may lead to lower levels of price sensitivity. Haddad and Hewings (2005), on the other hand, use a higher interregional trade elasticity for manufactured commodities as a whole in their CGE model for Brazil. This is close to the default value applied in the Illinois CGE model below (2.0), and also reflects the argument that interregional trade elasticities are generally higher than international ones.

In terms of the specific Illinois case reported here, note that Tobacco Products is a very small sector in Illinois and the elasticities here should not be interpreted as reflecting any significant market structure. On the other hand, transport equipment (especially the first level supply chain components) and Machinery and Electric Equipment are major sectors and produce products with a high degree of spatial substitutability. Further, many

of the components in these sectors are also part of complex value chains; the process of 
fragmentation (see Jones and Kierzkowski, 2005) has witnessed a significant transformation in the spatial allocation of production with the result that there is a great deal of intra-industry trade in these sectors generating increased competition and thus sensitivity to prices.

\section{Impact of introducing estimated import elasticities to a CGE model of the Illinois economy (AMOIL)}

We have constructed a CGE model of the Illinois state economy, AMOIL, using the AMOS framework calibrated on a 2007 Social Accounting Matrix (SAM). ${ }^{2}$ AMOS is a well-crafted modeling framework that allows the modeler to adopt a variety of perspectives concerning the operation of markets in small open economies, with particular attention to labor markets. It also offers a high degree of flexibility for the choice of key parameter values, model closures and even aggregate structure that allows the modeler to choose appropriate conditions for particular applications. Thus, it can be applied to a small open regional economy such as the Illinois region (which, in the context of the US as a whole, accounts for about $3 \%$ of national GNP). Detailed descriptions of the single region AMOS modeling framework can be found in Harrigan et al. (1991) and Ferguson et al. (2007). We give an overview of the model in Table 4. A condensed listing of the model variables and most important equations can be found at the journal's web-site with supporting material.

\section{<<Insert Table 4 here $>>$}

The key point for the testing of our estimated import elasticities is the specification of the production function and determination of the price of output. We employ a nested CES function for each of the 24 production sectors, where output is a combination of valueadded (capital and labor) and a composite intermediate input. Here, we assume that an

\footnotetext{
${ }^{2}$ AMOS is an acronym for a macro-micro model of Scotland, the regional economy on which the CGE modeling software was initially calibrated (Harrigan et al., 1991).
} 
elasticity of substitution of 0.3 applies at each of these nests throughout (this is the default AMOS value, previously applied for UK regions). While these production parameters should be the focus on region-specific estimation in future research, it is worth noting there that the lower the substitutability between the composite intermediate input and value added, the greater will be the impact on the sectoral output price of restricting substitutability between domestic and imported goods as local prices change, and vice versa.

The intermediate composite involves a combination of goods and services produced in the US and the rest of the world (ROW) in a CES function. At the bottom level of the nest, the US composite also involves a CES combination but of goods and services produced in Illinois and the rest of the US (RUS). We assume cost minimization so that if Illinois prices rise, there will be a substitution effect in favor of RUS goods. The degree of substitutability is governed by the value attached to the elasticity of substitution in this CES function. The default AMOS value is 2.0 and the results reported in this section involve testing the impact of introducing the (generally lower) estimated values reported in the previous section.

However, the current specification of the AMOS production and consumption functions involved composite goods rather than commodity level substitution possibilities between Illinois and RUS goods. Therefore, we need to adjust the estimates in Tables 1 and 2 to input them to the model. We adjust by first creating a weight matrix of commodity use for all Illinois sectors and final consumers. The numerator of each element is sector $j$ 's (consuming sector/final consumption activity) use of Illinois commodity $i$ plus RUS commodity $i$. The denominator is total intermediates from Illinois and RUS. We then take the vector of estimated commodity elasticities (for both Model 1 and 2) as a column and multiply each element by each row element of the weight matrix (i.e. for each production sector and final consumer in turn), before summing down the columns for each user. This results in a weighted Illinois-RUS substitution elasticity for each sector and final consumer that we can introduce to the CGE model for Estimation Models 1 and 2 in turn (see Table 5). Given that we have not been able to estimate elasticities for all commodities, we impose values for the non-estimated or missing commodities. In the simulations reported below, we focus on the better fitting Estimation 
Model 1 and the cases where we take the elastic AMOS default values of 2.0 and inelastic values of 0.5 for the non-estimated commodities. ${ }^{3}$ We also focus on results for the targeted sectors (where the greatest impact is felt) and on the variables impacting the adjustment of the economy.

\section{$<<$ Insert Table 5 here $>>$}

For illustrative purposes, we introduce a simple demand shock: A 5\% permanent step increase in ROW export demand for the outputs of the seven Illinois manufacturing sectors (9-15 in Appendix 1). Such a stimulus would be expected to increase long-run GDP, employment, consumption and investment in Illinois (we assume no other changes in economic conditions so that all deviations from the base year data can be attributed solely to the export demand shock). However, we as sume that there are short-run supply constraints: it takes time for investment to occur to increase capital stocks and also for labor stocks to increase through in-migration. In the first period after the demand stimulus occurs, the only excess capacity in primary inputs is unemployed labor. Thus, initially there is upward pressure on wages, capital rental rates and the price of output in all sectors, but particularly the targeted manufacturing sectors.

This is where the impact of varying the value of import elasticities is most important. In the simulations below, we focus our attention on the short-run and specifically on how the value assigned to the substitutability between Illinois and RUS intermediates impacts on input choices and output prices in the targeted sectors, and how these impact the returns to capital and labor driving the adjustment of the economy. Generally, under the assumption of cost minimization (or utility maximization), as capital and labor prices rise in the short run, there is upward pressure in the price of commodities produced in Illinois. This is dampened to the extent that producers can substitute away from value-added in favor of intermediates. As the price of goods and services produced in Illinois is pushed up, producers (and final consumers) will substitute in favor of imports from other US states in choosing their intermediate (goods and services) composite (and, to the extent

\footnotetext{
${ }^{3}$ In a fuller set of simu lations (not reported here) we find that there is not a great deal of difference in CGE model results if we use the parameter estimates from Estimation Model 1 or 2.
} 
that the US composite price is affected, in favor of ROW imports, though the dominance of US commodities in the intermediate composite of all sectors, the substitutability at this level of the production function is less important). ${ }^{4}$

\section{$<<$ Insert Table 6 here $>>$}

In the first numerical column of Table 6 we report the impact of the 5\% increase in ROW export demand on the use of imported intermediates from RUS in the targeted manufacturing sectors. Reading down from the AMOS default case we first impose only the estimated parameters and then a lower value of 0.5 for all the missing commodities. Observe that in each sector the increase in the use of RUS imports becomes smaller as the substitution effect becomes weaker.

However, examining the results for the use of Illinois commodities, while the substitution effect is negative (for sectors not directly targeted with the shock, this generally dominates, leading to a short run net decrease in the use of Illino is commodities), positive income effects from the exogenous increase in export demand causes a greater increase the lower the substitution elasticity. This is because local production is effectively protected in so far as, the more limited the ability to substitute in in favor of imports means that local producers must draw on local intermediates to meet increased consumption demand. This, in turn, is what causes the price of output in the targeted sectors to increase more with lower the import elasticities.

While the larger increase in output prices with lower elasticities restricts the growth of exports in response to the shock (because of the endogenous export demand response acting to offset the exogenous shock) it acts to increase the return on capital in each sector. This triggers a faster investment response where substitutability is lower. Moreover, the greater short-run increase in labor demand pushes the real wage level up and the unemployment rate down more quickly, so that a faster migration response also occurs. Thus, despite the initial spike in local prices and reduced competitiveness in the short-run, supply constraints are relaxed faster under the more restricted import elasticity,

\footnotetext{
${ }^{4}$ Again, in simulations not reported here, this conclusion has been tested but not reported here due to the constraints of space.
} 
so that the adjustment to a new long-run equilibrium is faster.

\section{Conclusions}

The econometric analysis conducted in this paper suggests that the interregional trade of transportation equipment, non-metallic mineral product, food and tobacco product and machinery and electric equipment are more sensitive to price differences than other commodities. Conversely, we find that more natural-resources based commodities have lower price elasticities. A possible explanation is that production of these commodities is regionally specialized and trade in them less dependent on price. These findings and interpretations seem to be consistent with the examination of Midwestern trade flows by Munroe et al. (2007). Using a Grubel-Lloyd Index, they show that Illinois appears to have high trade overlap in high-tech industries (e.g. food products, fabricated metal products, and machinery) and more specialized trade in low-tech industries (e.g. fish, coal, ordinance or accessories, petroleum or coal, and clay, concrete, class or stone).

Additionally, the interregional trade elasticities estimated here tend to be lower than those estimated with US data or international trade data elsewhere in the literature. Our results are consistent with the conclusions of Bilgic et al. (2002), who argue that trade elasticities for a regional CGE model should be considered less sensitive to differences in prices of intraregional trade goods versus interregional trade goods than in the country or international cases. This is in contrast with the more general expectation that regional trade elasticities should find their lower bound in international trade elasticities. A possible explanation as to why regional trade elasticities may be less price responsive than comparable commodity group elasticities for the US national case, or for international trade, may be that regional economies tend to specialize, with the amount of interregional trade driven by non-price barriers and lower transport costs. One option in investigating further would be to formally separate out transport costs in the production function to test the degree to which changes in these costs influence the spatial choice of inputs. Haddad and Hewings $(2005,2007)$ test this argument in the context of a multire gional CGE model for Brazil. 
The tests of the impact of introducing the estimated import elasticities into the Illinois CGE model demonstrate that these primarily impact on the initial response of the economy when labor and capital stocks are constrained. However, while more limited responsiveness to changes in Illinois prices does have implications in terms of competitiveness in the short-run, it also stimulates faster returns to factors of production, triggering a faster adjustment to a new long-run equilibrium. However, the CGE results also suggest that, while there is clear value added from the limited econometric parameterization reported here, it is important to attempt to widen the focus of econometric analysis to all sectors and commodities, including service sectors that are traded interregionally in the US. However, data availability is a problem in this respect, with the Commodity Flow Survey data here limited in terms of its scope.

\section{References}

Armington, P.S. (1969) A Theory of Demand for Products Distinguished by Place of Production. International Monetary Fund Staff Papers, 16, 159-176.

Bilgic, A., King, S., Lusby, A. and Schreiner, D.F. (2002) Estimation of U.S. Regional Commodity Trade Elasticities of Substitution. The Journal of Regional Analysis and Policy, 32, 79-98.

Blanchflower, D.G. and Oswald, A.J. (1994) The Wage Curve, M.I.T. Press, Cambridge, Massachusetts.

Bureau of Economic Analysis () Regional Economic Information System. Retrieved from http://www.bea.gov/regional/index.htm

Bureau of Labor Statistics () Quarterly Census of Employment and Wages. Retrieved from http://www.bls.gov/cew/data.htm

Bureau of Transportation Statistics (2005) Commodity Flow Survey 2002. Publication

Number: C1-E02-ECFS-00-US1. Washington, D.C., Research and Innovative Technology Administration (RITA), U.S. Department of Transportation.

Chung, J.W. (1994) Utility and Production Functions. Blackwell, Cambridge, Massachusetts,. 
DeVuyst, E.A., and P.V. Preckle (1997) Sensitivity Analysis Revisited: A QuadratureBased Approach. Journal of Policy Modeling, 19, 175-185.

Dixon, P.B., M.T. Rimmer and M.E. Tsigas (2007) Regionalising Results from a Detailed CGE Model: Macro, Industry and State Effects in the U.S. of Removing Major Tariffs and Quotas. Papers in Regional Science, 86, 31-55.

Erkel-Rousse, H., and D. Mirza (2002) Import Price Elasticities: Reconsidering the Evidence. Canadian Journal of Economics, 35, 282-306.

Ferguson, L., D. Learmonth, P. McGregor, J.K. Swales and K. Turner (2007) The Impact of the Barnett Formula on the Scottish Economy: Endogenous Population and Variable Formula Proportions. Environment and Planning A, 39, 3008-3027.

Haddad E. A. and G.J.D. Hewings (2005) Market Imperfections in a Spatial Economy: Some Experimental Results. The Quarterly Review of Economics and Finance 45, 476-496.

Haddad E.A. and GJ.D. Hewings (2007) Analytically Important Transportation Links: A Field of Influence Approach to CGE Models. Revista Brasileira de Estudos Regionais e Urbanos, 1, 63-84.

Harrigan, F., P.G McGregor, J.K. Swale, and N. Dourmashkin (1991) The Sensitivity of Output Multipliers to Alternative Technology and Factor Market Assumptions: A Computable General Equilibrium Analysis. In: Dewhurst J.H.L., R.C. Jensen, and G.J.D. Hewings (Eds.) Regional Input-Output Modeling: New Development and Interpretation. Aldershot, Avebury Press.

Harris, J.D. and M.P. Todaro (1970) Migration, Unemployment and Development: A Two Sector Analysis. American Economic Review, 60, 126-142.

Harrison, GW. and H.D. Vinod (1992) The Sensitivity Analysis of Applied General Equilibrium Models: Completely Randomized Factorial Sampling Designs. Review of Economics and Statistics, 74, 357-362.

Harrison, GW., R. Jones, L.J. Kimbell, and R. Wigle (1993) How Robust is Applied General Equilibrium Analysis? Journal of Policy Modeling, 15, 99-115.

Head, K. and T. Mayer (2000) Non-Europe: The Magnitude and Causes of Market Fragmentation in Europe. Weltwirtschaftliches Archiv, 136, 285-314.

Hertel, T.W. (1985) Partial vs. General Equilibrium Analysis and Choice of Functional 
Form: Implications for Policy Modeling. Journal of Policy Modeling, 7, 281-303.

Hewings, G.J.D. and J.B. Parr (2009) The Changing Structure of Trade and Interdependence in a Mature Economy: The US Midwest. In: P. McCann (Ed.) Technological Change and Mature Industrial Regions: Firms, Knowledge, and Policy. Cheltenham, UK, Edward Elgar, 64-84.

Hoffman, S., S. Robinson, and S. Subramanian (2006) The Role of Defense Cuts in the California Recession Computable General Equilibrium Models and Interstate Factor Mobility. Journal of Regional Science, 36, 571-595.

Holland, D. (2010) What Happens when Exports Expand: Some Ideas for Closure of Regional Computable General Equilibrium Models. Annals of Regional Science, 45, 439-451.

Jones, R.W. and H. Kierzkowski (2005) International Fragmentation and the New Economic Geography. North American Journal of Economics and Finance, 16, 1-10. Lawson, T. (1980) A 'Rational Modeling Procedure' (and the Estimating of Input-Output Coefficients). Economics of Planning, 16, 105-117.

Munroe, D.K., G.J.D. Hewings and D. Guo (2007) The Role of Intraindustry Trade in Interregional Trade in the Midwest of the U.S. In: Cooper, R.J., K.P. Donaghy and G.J.D. Hewings. (Eds.) Globalization and Regional Economic Modeling. Berlin, Springer.

Partridge, M.D. and D.S. Rickman. (1998) Regional Computable General Equilibrium Modeling: A Survey and Critical Appraisal. International Regional Science Review, 21, 205-248.

Partridge, M.D. and D.S. Rickman. (2010) Computable General Equilibrium (CGE) Modeling for Regional Economic Development Analysis. Regional Studies, 44, 1311-1328.

Reinert, K.A. and D.W. Roland-Holst (1992) Armington Elasticities for United States Manufacturing Sectors. Journal of Policy Modeling, 14, 531-639.

Romero, I., H.W.A. Dietzenbacher and G.J.D. Hewings. (2009) Fragmentation and Complexity: Analyzing Structural Change in the Chicago Regional Economy. Revista de Economía Mundial, 23, 263-282.

Seung, C.K., and E.C. Waters (2010) Evaluating Supply-Side and Demand-Side Shocks 
for Fisheries: A Computable General Equilibrium (CGE) model for Alaska. Economics Systems Research, 22, 87-109.

Shiells, C.R. and K.A. Reinert (1993) Armington Models and Terms-of-Trade Effects: Some Econometric Evidence for North America. Canadian Journal of Economics, 26, 299-316.

Shiells, C.R., R.M. Stern, and A.V. Deardorff. (1986) Estimates of the Elasticities of Substitution between Imports and Home Goods for the United States. Review of World Economics, 122, 497-519.

Stern, R.M., J. Francis and B. Schumacher (1976) Price Elasticities in International Trade: An Annotated Bibliography. London, Macmillan Press. 


\section{Appendix 1. Sectoral breakdown of the Illinois CGE Model (AMOIL)}

Illinois CGE sector

01. Agriculture, Forestry, Fish \& Hunting

02. Oil \& Gas Extraction

03. Mining (except Oil and Gas)

04. Support Activities for Mining

05. Electricity

06. Natural Gas

07. Water, sewage and other systems

08. Construction

09. Food, Beverage, and Tobacco Product Manufacturing

10. Textile, Apparel, and Leather Product Manufacturing

11. Paper Manufacturing and Printing Related Activities

12. Chemical Products Manufacturing

13. Primary Metal and Metal Product Manufacturing

14. Machinery and Equipment Manufacturing

15. Wood, Furniture, and Miscellaneous Manufacturing

16. Wholesale trade

17. Retail trade

18. Transportation and warehousing

19. Finance, insurance, and Management of companies/enterprises

20. Educational services

21. Health care and social assistance

22. Accommodation and food services

23. All Other Services, including Information, Real Estate \& Rental, Professional \& Tech Services etc

24. Government Enterprises 


\section{APPENDIX 2. A CONDENSED VERSION OF AMOIL}

\begin{tabular}{|c|c|}
\hline Equations & trun \\
\hline (1) Gross Output Price & $p q_{i}=p q_{i}\left(p v_{i}, p m_{i}\right)$ \\
\hline (2) Value Added Price & $p v_{i}=p v_{i}\left(w_{n}, w_{k, i}\right)$ \\
\hline (3) Intermediate Composite Price & $p m_{i}=p m_{i}(p q)$ \\
\hline (4) Wage setting & $w_{n}=w_{n}\left(\frac{N}{L}, c p i, t_{n}\right)$ \\
\hline (5) Labor force & $L=\bar{L}$ \\
\hline (6) Consumer price index & $c p i=\sum_{i} \theta_{i} p q_{i}+\sum_{i} \theta_{i}^{R U S} \overline{p q}^{R U S}+\sum_{i} \theta_{i}^{R O W} p \bar{q}^{\text {ROW }}$ \\
\hline (7) Capital supply & $K_{i}^{s}=\bar{K}_{i}^{s}$ \\
\hline (8) Capital price index & $k p i=\sum_{i} \gamma_{i} p q_{i}+\sum_{i} \gamma_{i}^{R U S} \overline{p q}^{R U S}+\sum_{i} \gamma_{i}^{R O W} p \bar{q}^{\text {ROW }}$ \\
\hline (9) Labor demand & $N_{i}^{d}=N_{i}^{d}\left(V_{i}, w_{n}, w_{k, i}\right)$ \\
\hline (10) Capital demand & $K_{i}^{d}=K_{i}^{d}\left(V_{i}, w_{n}, w_{k, i}\right)$ \\
\hline (11) Labor market clearing & $N^{s}=\sum_{i} N_{i}^{d}=N$ \\
\hline (12) Capital market clearing & $K_{i}^{s}=K_{i}^{d}$ \\
\hline (13) Household income & $Y=\Psi_{n} N w_{n}\left(1-t_{n}\right)+\Psi_{k} \sum_{i} w_{k, i}\left(1-t_{k}\right)+\bar{T}$ \\
\hline (14) Commodity demand & $Q_{i}=C_{i}+I_{i}+G_{i}+X_{i}+R_{i}$ \\
\hline (15) Consumption Demand & $C_{i}=C_{i}\left(p q_{i}, \bar{p} q_{i}^{R U S}, \bar{p} q_{i}^{R O W}, Y, c p i\right)$ \\
\hline
\end{tabular}




\begin{tabular}{|c|c|}
\hline (16) Investment Demand & $\begin{array}{c}I_{i}=I_{i}\left(p q_{i}, \bar{p} q_{i}^{R U S}, \bar{p} q_{i}^{R O W}, \sum_{i} b_{i, j} I_{j}^{d}\right) \\
I_{j}^{d}=h_{j}\left(K_{j}^{d}-K_{j}\right)\end{array}$ \\
\hline (17) Government Demand & $G_{i}=\bar{G}_{i}$ \\
\hline (18) Export Demand & $X_{i}=X_{i}\left(p_{i}, \bar{p}_{i}^{R U S}, \bar{p}_{i}^{R O W}, \bar{D}^{R U S}, \bar{D}^{R O W}\right)$ \\
\hline (19) Intermediate Demand & $\begin{array}{c}R_{i, j}^{d}=R_{i}^{d}\left(p q_{i}, p m_{j}, M_{j}\right) \\
R_{i}^{d}=\sum_{j} R_{i, j}^{d}\end{array}$ \\
\hline $\begin{array}{l}\text { (20) Intermediate Composite } \\
\text { Demand }\end{array}$ & $M_{i}=M_{i}\left(p v_{i}, p m_{i}, Q_{i}\right)$ \\
\hline (21) Value Added Demand & $V_{i}=V_{i}\left(p v_{i}, p m_{i}, Q_{i}\right)$ \\
\hline Multi-period model & Stock up-dating equations \\
\hline (22) Labor force & $L_{t}=L_{t-1}+n m g_{t-1}$ \\
\hline (23) Migration & $\frac{n m g}{L}=n m g\left(\frac{w_{n}\left(1-t_{n}\right)}{c p i}, \frac{w_{n}^{R U S}\left(1-t_{n}\right)}{c p i^{R U S}}, u, u^{R U S}\right.$ \\
\hline (24) Capital Stock & $K_{i, t}=\left(1-d_{i}\right) K_{i, t-1}+I_{i, t-1}^{d}$ \\
\hline
\end{tabular}

\section{NOTATION}

\section{Activity-Commodities}

$i, j$ are, respectively, the activity and commodity subscripts (There are twenty-four of each in AMOIL: see Appendix 1)

\section{Transactors}

RUS $=$ Rest of the US, ROW $=$ Rest of World

\section{Functions}




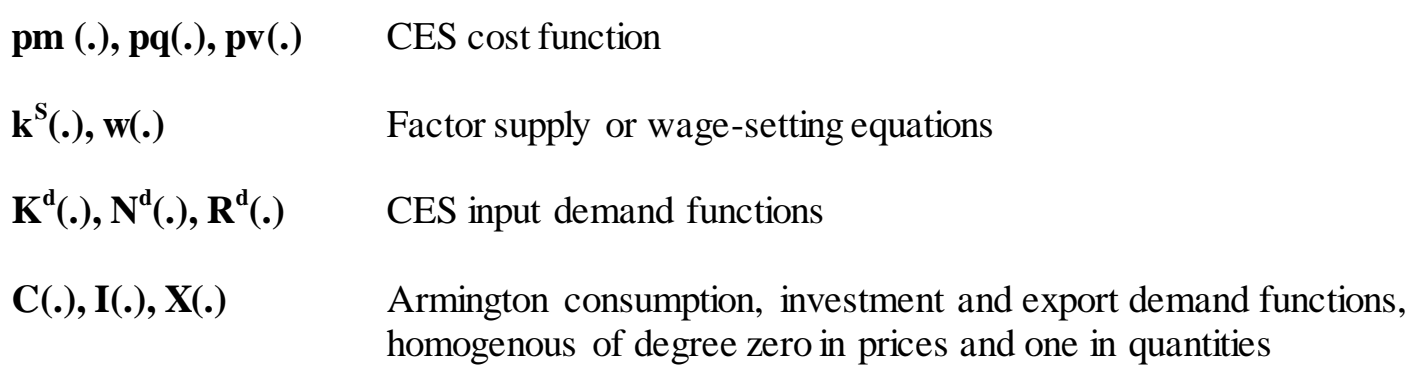

\section{Variables and parameters}

C

consumption

D exogenous export demand

G government demand for local goods

I investment demand for local goods

$\mathbf{I}^{\mathbf{d}} \quad$ investment demand by activity

$\mathbf{K}^{\mathbf{d}}, \mathbf{K}^{\mathbf{S}}, \mathbf{K} \quad$ capital demand, capital supply and capital employment

L labor force

M intermediate composite output

$\mathbf{N}^{\mathrm{d}}, \mathbf{N}^{\mathrm{S}}, \mathbf{N} \quad$ labor demand, labor supply and labor employment

Q commodity/activity output

R intermediate demand

T nominal transfers from outwith the region

V value added

$\mathbf{X} \quad$ exports

Y household nominal income

$\mathbf{b}_{\mathrm{ij}} \quad$ elements of capital matrix

cpi, kpiconsumer and capital price indices

d physical depreciation

h capital stock adjustment parameter 


$\begin{array}{ll}\mathbf{n m g} & \text { net migration } \\ \mathbf{p m} & \text { price intermediate composite } \\ \mathbf{p q} & \text { vector of commodity prices } \\ \mathbf{p v} & \text { price of value added } \\ \mathbf{t}_{\mathbf{n}}, \mathbf{t}_{\mathbf{k}} & \text { average direct tax on labor and capital income } \\ \mathbf{u} & \text { unemployment rate } \\ \mathbf{W} & \text { price of labor to the firm, capital rental } \\ \Psi & \text { share of factor income retained in region } \\ \boldsymbol{\theta} & \text { consumption weights } \\ \gamma & \text { capital weights }\end{array}$


Table 1 Import elas ticity estimates using Estimation Model 1 (Equation 8)

\begin{tabular}{|c|c|c|c|c|c|}
\hline & Commodity & $\begin{array}{c}\text { Elasticity } \\
\sigma\end{array}$ & $\begin{array}{l}\text { Market } \\
\text { Size } \delta_{1}\end{array}$ & $\begin{array}{l}\text { Distance } \\
\text { Factor } \delta_{2}\end{array}$ & $\mathrm{R}^{2}$ \\
\hline 1 & $\begin{array}{llll}\text { Agriculture, } & \text { Forestry, Fish } \& \\
\text { Hunting }\end{array}$ & $\begin{array}{l}0.919 * * * \\
0.156\end{array}$ & $\begin{array}{l}2.699 * * * \\
0.165\end{array}$ & $\begin{array}{l}2.282^{* * * *} \\
0.111\end{array}$ & 0.962 \\
\hline $2,3,4$ & $\begin{array}{l}\text { Oil \& Gas Extraction, Mining, and } \\
\text { Support Activities for Mining }\end{array}$ & $\begin{array}{l}0.814 * * * \\
0.082\end{array}$ & $\begin{array}{l}0.968 * * * \\
0.138\end{array}$ & $\begin{array}{l}3.401 * * * \\
0.092\end{array}$ & 0.927 \\
\hline 9 & $\begin{array}{l}\text { Food, Beverage and Tobacco } \\
\text { Products Manufacturing }\end{array}$ & $\begin{array}{l}1.282^{* * *} \\
0.169\end{array}$ & $\begin{array}{l}0.513^{* * *} \\
0.100\end{array}$ & $\begin{array}{l}1.022^{* * *} \\
0.106\end{array}$ & $\overline{0.880}$ \\
\hline 10 & $\begin{array}{l}\text { Textile, Apparel, and Leather } \\
\text { Product Manufacturing }\end{array}$ & $\begin{array}{l}0.068^{*} \\
0.112\end{array}$ & $\begin{array}{l}9.909 * * * \\
0.050\end{array}$ & $\begin{array}{l}17.287 \\
0.048\end{array}$ & 0.926 \\
\hline 11 & $\begin{array}{l}\text { Paper Manufacturing and Printing } \\
\text { Related Activities }\end{array}$ & $\begin{array}{l}0.850^{* * * *} \\
0.076\end{array}$ & $\begin{array}{l}1.099 * * * \\
0.080\end{array}$ & $\begin{array}{l}1.327 * * * \\
0.070\end{array}$ & 0.910 \\
\hline 12 & Chemical Products Manufacturing & & & & \\
\hline $12 \mathrm{a}$ & Chemical and Petroleum Products & $\begin{array}{l}0.712 * * * \\
0.055\end{array}$ & $\begin{array}{l}1.336^{* * * *} \\
0.064\end{array}$ & $\begin{array}{l}1.746^{* * *} \\
0.074\end{array}$ & 0.956 \\
\hline $12 \mathrm{~b}$ & Non-Metallic Mineral Products & $\begin{array}{l}1.357 * * * \\
0.083\end{array}$ & $\begin{array}{l}0.489 * * * \\
0.094\end{array}$ & $\begin{array}{l}0.945^{* * *} \\
0.099\end{array}$ & 0.985 \\
\hline 13 & $\begin{array}{l}\text { Primary Metal and Metal Product } \\
\text { Manufacturing }\end{array}$ & $\begin{array}{l}0.922 * * * \\
0.078\end{array}$ & $\begin{array}{l}1.057 * * * \\
0.078\end{array}$ & $\begin{array}{l}1.390 * * * \\
0.056\end{array}$ & 0.977 \\
\hline 14 & $\begin{array}{l}\text { Machinery and Equipment } \\
\text { Manufacturing }\end{array}$ & & & & \\
\hline $14 \mathrm{a}$ & Machinery and Electric Equipment & $\begin{array}{l}1.012^{* * *} \\
0.090\end{array}$ & $\begin{array}{l}0.986 * * * \\
0.072\end{array}$ & $\begin{array}{l}0.898 * * * \\
0.067\end{array}$ & 0.932 \\
\hline $14 \mathrm{~b}$ & Transportation Equipment & $\begin{array}{l}1.517 * * * \\
0.231\end{array}$ & $\begin{array}{l}0.415^{* * *} \\
0.079\end{array}$ & $\begin{array}{l}0.922^{* * *} \\
0.063\end{array}$ & 0.926 \\
\hline $14 \mathrm{c}$ & $\begin{array}{l}\text { Medical, Precision and Optical } \\
\text { Instrument }\end{array}$ & $\begin{array}{l}0.2 \overline{8} 6^{*} \text { *** } \\
0.102\end{array}$ & $\begin{array}{l}2.4 \overline{2} 8^{* * *} \\
0.047\end{array}$ & $\begin{array}{l}2.722^{* * * * *} \\
0.023\end{array}$ & 0.946 \\
\hline 15 & $\begin{array}{lll}\text { Wood, } \quad \text { Furniture, } & \text { and } \\
\text { Miscellaneous } & \text { Manufacturing }\end{array}$ & & & & \\
\hline $15 \mathrm{a}$ & Wood Products and Furniture & $\begin{array}{l}0.941^{* * *} \\
0.079\end{array}$ & $\begin{array}{l}1.082^{* * *} \\
0.126\end{array}$ & $\begin{array}{l}1.343^{* * *} \\
0.088\end{array}$ & 0.770 \\
\hline $15 b$ & Miscellaneous Manufacturing & $\begin{array}{l}0.619^{* * *} \\
0.121\end{array}$ & $\begin{array}{l}1.506^{* *} \\
0.058\end{array}$ & $\begin{array}{l}1.919^{* * *} \\
0.068\end{array}$ & 0.973 \\
\hline
\end{tabular}

1) Standard errors are in Italics

2) $* * *$ significant at $1 \%$, ** at $5 \%$, and $*$ at $10 \%$ 
Table 2 Import elasticity estimates using Model 2 (equation 10)

\begin{tabular}{|c|c|c|c|c|c|}
\hline & Commodity & $\begin{array}{l}\text { Elasticity } \\
\sigma\end{array}$ & $\begin{array}{l}\text { Market } \\
\text { size } \delta_{1}\end{array}$ & $\begin{array}{l}\text { Distance } \\
\text { factor } \delta_{2}\end{array}$ & $\mathrm{R}^{2}$ \\
\hline 1 & Agriculture, Forestry, Fish \& Hunting & $\begin{array}{l}0.645^{* *} \\
0.302\end{array}$ & $\begin{array}{l}3.458^{* * *} \\
0.431\end{array}$ & $\begin{array}{l}1.403 * * * \\
0.283\end{array}$ & 0.663 \\
\hline $2,3,4$ & $\begin{array}{l}\text { Oil \& Gas Extraction, Mining, and } \\
\text { Support Activities for Mining }\end{array}$ & $\begin{array}{l}0.963 * * * \\
0.147\end{array}$ & $\begin{array}{l}0.669 * * * \\
0.254\end{array}$ & $\begin{array}{l}0.974 * * \\
0.383\end{array}$ & 0.723 \\
\hline 9 & $\begin{array}{l}\text { Food, Beverage and Tobacco Products } \\
\text { Manufacturing }\end{array}$ & $\begin{array}{l}1.093^{* * *} \\
0.229\end{array}$ & $\begin{array}{l}1.329 * * * \\
0.288\end{array}$ & $\begin{array}{l}0.900^{* * * *} \\
0.278\end{array}$ & 0.410 \\
\hline 10 & $\begin{array}{l}\text { Textile, Apparel, and Leather Product } \\
\text { Manufacturing }\end{array}$ & $\begin{array}{l}0.421^{*} \\
0.251\end{array}$ & $\begin{array}{l}1.512^{* * * *} \\
0.132\end{array}$ & $\begin{array}{l}0.062 \\
0.191\end{array}$ & 0.561 \\
\hline 11 & $\begin{array}{l}\text { Paper Manufacturing and Printing } \\
\text { Related Activities }\end{array}$ & $\begin{array}{l}0.868^{* * * *} \\
0.086\end{array}$ & $\begin{array}{l}1.611^{* * *} \\
0.118\end{array}$ & $\begin{array}{l}0.772^{* * * *} \\
0.122\end{array}$ & 0.809 \\
\hline 12 & Chemical Products Manufacturing & & & & \\
\hline $12 \mathrm{a}$ & Chemical and Petroleum Products & $\begin{array}{l}0.675^{* * *} \\
0.076\end{array}$ & $\begin{array}{l}1.935^{* * *} \\
0.093\end{array}$ & $\begin{array}{l}0.682^{* * *} \\
0.113\end{array}$ & 0.830 \\
\hline $12 b$ & Non-Metallic Mineral Products & $\begin{array}{l}2.169^{* * *} \\
0.125\end{array}$ & $\begin{array}{l}0.443^{* * *} \\
0.242\end{array}$ & $\begin{array}{l}0.047 \\
0.106\end{array}$ & 0.953 \\
\hline 13 & $\begin{array}{l}\text { Primary Metal and Metal Product } \\
\text { Manufacturing }\end{array}$ & $\begin{array}{l}1.016^{* *} \\
0.169\end{array}$ & $\begin{array}{l}1.245^{* * * *} \\
0.168\end{array}$ & $\begin{array}{l}0.349 * * \\
0.181\end{array}$ & 0.812 \\
\hline 14 & $\begin{array}{lll}\text { Machinery } & \text { and } & \text { Equipment } \\
\text { Manufacturing } & & \end{array}$ & & & & \\
\hline $14 \mathrm{a}$ & Machinery and Electric Equipment & $\begin{array}{l}1.336^{* * * *} \\
0.117\end{array}$ & $\begin{array}{l}0.753 * * * \\
0.158\end{array}$ & $\begin{array}{l}0.065 \\
0.159\end{array}$ & 0.791 \\
\hline $14 \mathrm{~b}$ & Transportation Equipment & $\begin{array}{l}1.905^{* * *} \\
0.338\end{array}$ & $\begin{array}{l}0.491 * * * \\
0.129\end{array}$ & $\begin{array}{l}0.184 * * \\
0.149\end{array}$ & 0.759 \\
\hline $14 \mathrm{c}$ & $\begin{array}{l}\text { Medical, Precision and Optical } \\
\text { Instrument }\end{array}$ & $\begin{array}{l}0.186 \\
0.330\end{array}$ & $\begin{array}{l}2.884^{*} \\
0.316\end{array}$ & $\begin{array}{l}0.535 \\
0.374\end{array}$ & 0.567 \\
\hline 15 & $\begin{array}{l}\text { Wood, Furniture, and Miscellaneous } \\
\text { Manufacturing }\end{array}$ & & & & \\
\hline $15 \mathrm{a}$ & Wood Products and Furniture & $\begin{array}{l}0.947^{* * *} \\
0.084\end{array}$ & $\begin{array}{l}1.416^{* * *} \\
0.170\end{array}$ & $\begin{array}{l}0.433^{* * *} \\
0.151\end{array}$ & 0.778 \\
\hline $15 b$ & Miscellaneous Manufacturing & $\begin{array}{l}1.007^{* * * *} \\
0.283\end{array}$ & $\begin{array}{l}1.098^{* * * *} \\
0.200\end{array}$ & $\begin{array}{l}0.167 \\
0.234\end{array}$ & 0.638 \\
\hline
\end{tabular}

1) Standard errors are in Italics

2) $* * *$ significant at $1 \%, * *$ at $5 \%$, and $*$ at $10 \%$ 
Table 3 Comparison of current study import elasticity estimates with others

\begin{tabular}{|c|c|c|c|c|c|c|c|}
\hline Sector & Commodity & $\begin{array}{c}\text { Eq. } \\
8\end{array}$ & Eq. 10 & $\begin{array}{l}\text { Bilgic et } \\
\text { al. } \\
(2002)\end{array}$ & $\begin{array}{c}\text { Reinert } \\
\text { and } \\
\text { Roland- } \\
\text { Holst } \\
\text { (1992) }\end{array}$ & $\begin{array}{l}\text { Shiells et } \\
\text { al. (1983) }\end{array}$ & $\begin{array}{c}\text { Erkel- } \\
\text { Rousse } \\
\text { and Mirza } \\
(2002)\end{array}$ \\
\hline 1 & $\begin{array}{c}\text { Agriculture, Forestry, Fish } \\
\text { \& Hunting }\end{array}$ & 0.919 & 0.645 & 1.477 & N/A & N/A & N/A \\
\hline $2,3,4$ & $\begin{array}{l}\text { Oil \& Gas Extraction, } \\
\text { Mining, and Support } \\
\text { Activities for Mining }\end{array}$ & 0.814 & 0.963 & 1.837 & 1.012 & N/A & N/A \\
\hline 9 & $\begin{array}{l}\text { Food, Beverage, and } \\
\text { Tobacco Product } \\
\text { Manufacturing }\end{array}$ & 1.282 & 1.093 & 0.516 & 1.049 & 0.338 & $\begin{array}{l}0.75 \sim \\
3.898\end{array}$ \\
\hline 10 & $\begin{array}{l}\text { Textile, Apparel, and } \\
\text { Leather Product } \\
\text { Manufacturing }\end{array}$ & 0.068 & 0.421 & $\begin{array}{c}0.290 \sim \\
0.625\end{array}$ & $\begin{array}{c}0.815 \sim \\
0.858\end{array}$ & $\begin{array}{c}1.620 \sim \\
2.580\end{array}$ & $\begin{array}{c}0.625 \sim \\
6.258\end{array}$ \\
\hline 11 & $\begin{array}{l}\text { Paper Manufacturing and } \\
\text { Printing Related Activities }\end{array}$ & 0.850 & 0.868 & 1.184 & 1.351 & 1.800 & $\begin{array}{l}1.023 \sim \\
5.687\end{array}$ \\
\hline 12 & $\begin{array}{l}\text { Chemical Products } \\
\text { Manufacturing }\end{array}$ & & & & & & \\
\hline & $\begin{array}{c}\text { (Chemical and Petroleum } \\
\text { Products) }\end{array}$ & 0.712 & 0.675 & $\begin{array}{l}0.891 \sim \\
2.872\end{array}$ & $\begin{array}{l}0.400 \sim \\
1.097\end{array}$ & $\begin{array}{c}6.740 \sim \\
6.979\end{array}$ & $\begin{array}{l}1.021 \sim \\
5.881\end{array}$ \\
\hline & $\begin{array}{l}\text { (Non-Metallic Mineral } \\
\text { Products) }\end{array}$ & 1.357 & 2.169 & $\begin{array}{c}0.843 \sim \\
1.106\end{array}$ & $\begin{array}{c}0.661 \sim \\
0.706\end{array}$ & $\begin{array}{l}1.540 \sim \\
2.696\end{array}$ & $\begin{array}{l}0.758 \sim \\
12.695\end{array}$ \\
\hline 13 & $\begin{array}{l}\text { Primary Metal and Metal } \\
\text { Product Manufacturing }\end{array}$ & 0.922 & 1.016 & 1.745 & 0.915 & 2.598 & $\begin{array}{c}0.927 \sim \\
5.146\end{array}$ \\
\hline 14 & $\begin{array}{l}\text { Machinery and Equipment } \\
\text { Manufacturing }\end{array}$ & & & & & & \\
\hline & $\begin{array}{l}\text { (Machinery and Electric } \\
\text { Equipment) }\end{array}$ & 1.012 & 1.336 & $\begin{array}{c}0.596 \sim \\
0.848\end{array}$ & $\begin{array}{c}0.347 \sim \\
0.834\end{array}$ & $\begin{array}{c}3.340 \sim \\
7.460\end{array}$ & $\begin{array}{c}0.781 \sim \\
2.511\end{array}$ \\
\hline & (Transportation Equip) & 1.517 & 1.905 & 0.600 & 0.969 & 3.010 & $\begin{array}{l}0.793 \sim \\
7.547\end{array}$ \\
\hline & $\begin{array}{l}\text { (Medical, Precision and } \\
\text { Optical Instrument) }\end{array}$ & 0.286 & 0.186 & 0.396 & 0.788 & 0.450 & $\begin{array}{l}0.986 \sim \\
2.176\end{array}$ \\
\hline 15 & $\begin{array}{l}\text { Wood, Furniture, and } \\
\text { Miscellaneous } \\
\text { Manufacturing }\end{array}$ & & & & & & \\
\hline & $\begin{array}{l}\text { (Wood Products and } \\
\text { Furniture) }\end{array}$ & 0.941 & 0.947 & $\begin{array}{c}0.931 \sim \\
1.429\end{array}$ & $\begin{array}{c}0.050 \sim \\
1.838\end{array}$ & $\begin{array}{l}0.260 \sim \\
12.130\end{array}$ & $\begin{array}{l}0.898 \sim \\
9.583\end{array}$ \\
\hline & $\begin{array}{l}\text { (Miscellaneous } \\
\text { Manufacturing) }\end{array}$ & 0.619 & 1.007 & 0.654 & 0.140 & 3.550 & $\begin{array}{c}0.861 \sim \\
1.607\end{array}$ \\
\hline \multicolumn{2}{|c|}{ Country/region estimates apply to } & \multicolumn{2}{|c|}{ IL } & $\begin{array}{l}\text { US (all } \\
\text { states) }\end{array}$ & $\begin{array}{c}\mathrm{US} \\
\text { national }\end{array}$ & $\begin{array}{c}\mathrm{US} \\
\text { national }\end{array}$ & $\begin{array}{l}\text { OECD } \\
\text { countries }\end{array}$ \\
\hline
\end{tabular}


Table 4. Overview of assumptions in the Illinois CGE model

\begin{tabular}{|c|c|}
\hline Variable & Assumption \\
\hline Domestic transactors & Three groups: the household sector; firms; and government \\
\hline Commodities/activities & 24 in total (see Appendix 1) \\
\hline Final demand & $\begin{array}{l}\text { Four components: household consumption (a linear homogeneous } \\
\text { function of real disposable income); investment (see under 'capital } \\
\text { stock' below); government expenditure (exogenous in this } \\
\text { application); and export demand }\end{array}$ \\
\hline External transactors & $\begin{array}{l}\text { Two exogenous external transactors: the Rest of the US (RUS) and } \\
\text { the Rest of the World (ROW), with demand for exports and imports } \\
\text { sensitive to changes in relative prices between (endogenous) } \\
\text { domestic/regional and (exogenous) external prices. }\end{array}$ \\
\hline Production costs & $\begin{array}{l}\text { Cost-minimization in production regardless of the choice of other } \\
\text { values }\end{array}$ \\
\hline Production structure & $\begin{array}{l}\text { A multi-level nested function in each production sector, where } \\
\text { output is a combination of value-added (capital and labor) and } \\
\text { intermediate inputs. The intermediates composite is a combination } \\
\text { of (composite) imports from ROW and US intermediates, with the } \\
\text { latter a combination of composite imports from RUS and domestic } \\
\text { production. The functional form at each nest is generally CES, with } \\
\text { Leontief and Cobb Douglas available as special cases. }\end{array}$ \\
\hline Capital stock & $\begin{array}{l}\text { Updated between time periods to ensure that investment equals } \\
\text { depreciation plus some fraction of the gap between the desired and } \\
\text { actual capital stock }\end{array}$ \\
\hline Labor market & $\begin{array}{l}\text { A single Illinois labor market with perfect sectoral mobility and real } \\
\text { wages determination via a regional bargaining closure, with a } \\
\text { negative relationship between the unemployment and real wage rate } \\
\text { (Blanchflower and Oswald, 1994) }\end{array}$ \\
\hline Migration & $\begin{array}{l}\text { Endogenous, with the population update between time periods } \\
\text { related to the real wage differential and the unemployment rate } \\
\text { differential between Illinois and RUS (Harris and Todaro, 1970) }\end{array}$ \\
\hline
\end{tabular}


Table 5. Weighted import elasticity estimates

\begin{tabular}{|c|c|c|c|c|c|c|c|}
\hline \multirow[b]{3}{*}{ Sector } & \multirow[b]{3}{*}{ Amo } & \multicolumn{3}{|c|}{ Model 1 results } & \multicolumn{3}{|c|}{ Model 2 results } \\
\hline & & \multicolumn{3}{|c|}{$\begin{array}{l}\text { Elasticity values imposed for } \\
\text { missing commodities }\end{array}$} & \multicolumn{3}{|c|}{$\begin{array}{l}\text { Elasticity values imposed } \\
\text { for missing commodities }\end{array}$} \\
\hline & & 0.5 & 1 & 2 & 0.5 & 1 & 2 \\
\hline 1 & $\begin{array}{l}\mathrm{s} \\
2\end{array}$ & 0.817 & 1.002 & 1.370 & 0.786 & 0.971 & 1.339 \\
\hline 2 & 2 & 0.622 & 0.967 & 1.657 & 0.684 & 1.029 & 1.718 \\
\hline 3 & 2 & 0.667 & 0.947 & 1.508 & 0.748 & 1.028 & 1.589 \\
\hline 4 & 2 & 0.698 & 0.981 & 1.545 & 0.796 & 1.079 & 1.643 \\
\hline 5 & 2 & 0.667 & 0.927 & 1.446 & 0.754 & 1.013 & 1.533 \\
\hline 6 & 2 & 0.716 & 0.880 & 1.208 & 0.819 & 0.983 & 1.312 \\
\hline 7 & 2 & 0.532 & 0.998 & 1.929 & 0.551 & 1.016 & 1.948 \\
\hline 8 & 2 & 0.722 & 0.970 & 1.466 & 0.849 & 1.097 & 1.593 \\
\hline 9 & 2 & 0.896 & 1.049 & 1.354 & 0.805 & 0.957 & 1.262 \\
\hline 10 & 2 & 0.586 & 0.785 & 1.183 & 0.784 & 0.983 & 1.381 \\
\hline 11 & 2 & 0.723 & 0.935 & 1.360 & 0.782 & 0.994 & 1.419 \\
\hline 12 & 2 & 0.804 & 0.964 & 1.282 & 0.995 & 1.154 & 1.473 \\
\hline 13 & 2 & 0.754 & 0.957 & 1.362 & 0.832 & 1.035 & 1.441 \\
\hline 14 & 2 & 0.781 & 0.959 & 1.313 & 0.906 & 1.083 & 1.438 \\
\hline 15 & 2 & 0.716 & 0.924 & 1.339 & 0.802 & 1.009 & 1.424 \\
\hline 16 & 2 & 0.549 & 0.991 & 1.876 & 0.576 & 1.019 & 1.904 \\
\hline 17 & 2 & 0.532 & 0.989 & 1.902 & 0.551 & 1.008 & 1.921 \\
\hline 18 & 2 & 0.653 & 0.998 & 1.689 & 0.751 & 1.096 & 1.786 \\
\hline 19 & 2 & 0.508 & 0.998 & 1.979 & 0.511 & 1.001 & 1.982 \\
\hline 20 & 2 & 0.585 & 1.014 & 1.871 & 0.587 & 1.015 & 1.873 \\
\hline 21 & 2 & 0.616 & 0.998 & 1.761 & 0.668 & 1.050 & 1.813 \\
\hline 22 & 2 & 0.725 & 1.053 & 1.709 & 0.704 & 1.032 & 1.688 \\
\hline 23 & 2 & 0.545 & 0.993 & 1.888 & 0.568 & 1.015 & 1.911 \\
\hline 24 & 2 & 0.668 & 0.987 & 1.624 & 0.769 & 1.087 & 1.724 \\
\hline $\mathrm{HH}$ & 2 & 0.592 & 1.010 & 1.816 & 0.616 & 1.024 & 1.839 \\
\hline GOVT & 2 & 0.558 & 0.995 & 1.869 & 0.583 & 1.020 & 1.894 \\
\hline CAPITAL & 2 & 0.636 & 0.976 & 1.654 & 0.701 & 1.040 & 1.719 \\
\hline
\end{tabular}


Table 6. Impacts of a 5\% increase in ROW export demand for Illinois manufacturing sectors on key adjustment variables

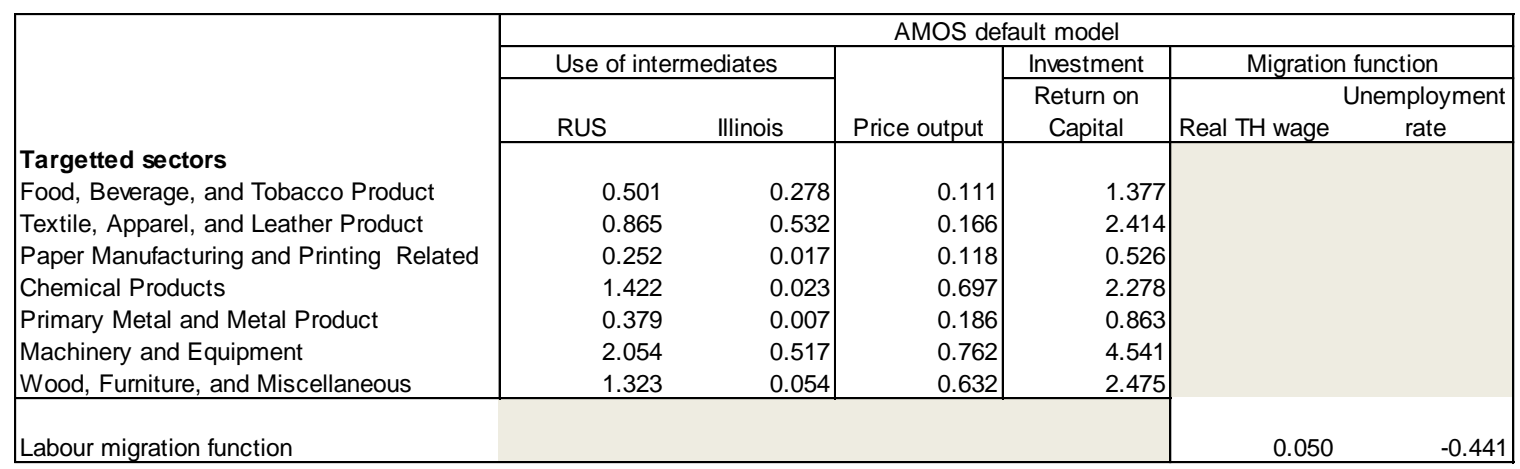

\begin{tabular}{|c|c|c|c|c|c|c|}
\hline \multirow{4}{*}{ Targetted sectors } & \multicolumn{6}{|c|}{$\begin{array}{l}\text { Estimation Model } 1 \text { (missing commomodities 2.0) } \\
\end{array}$} \\
\hline & \multicolumn{2}{|c|}{ Use of intermediates } & \multirow[b]{2}{*}{ Price output } & \multirow{2}{*}{\begin{tabular}{|c|} 
Investment \\
Return on \\
Capital \\
\end{tabular}} & \multicolumn{2}{|c|}{ Migration function } \\
\hline & RUS & Illinois & & & Real TH wage & $\begin{array}{c}\text { Unemployment } \\
\text { rate }\end{array}$ \\
\hline & 0.472 & 0.315 & 0.116 & 1392 & & \\
\hline Textile, Apparel, and Leather Product & 0.786 & 0.580 & 0.173 & 2.415 & & \\
\hline Paper Manufacturing and Printing Related & 0.209 & 0.040 & 0.124 & 0.495 & & \\
\hline Chemical Products & 1.139 & 0.181 & 0.745 & 2.426 & & \\
\hline Primary Metal and Metal Product & 0.328 & 0.070 & 0.190 & 0.850 & & \\
\hline Machinery and Equipment & 1.791 & 0.748 & 0.787 & 4.654 & & \\
\hline Wood, Furniture, and Miscellaneous & 1.103 & 0.227 & 0.652 & 2.520 & & \\
\hline Labour migration function & & & & & 0.056 & -0.494 \\
\hline
\end{tabular}

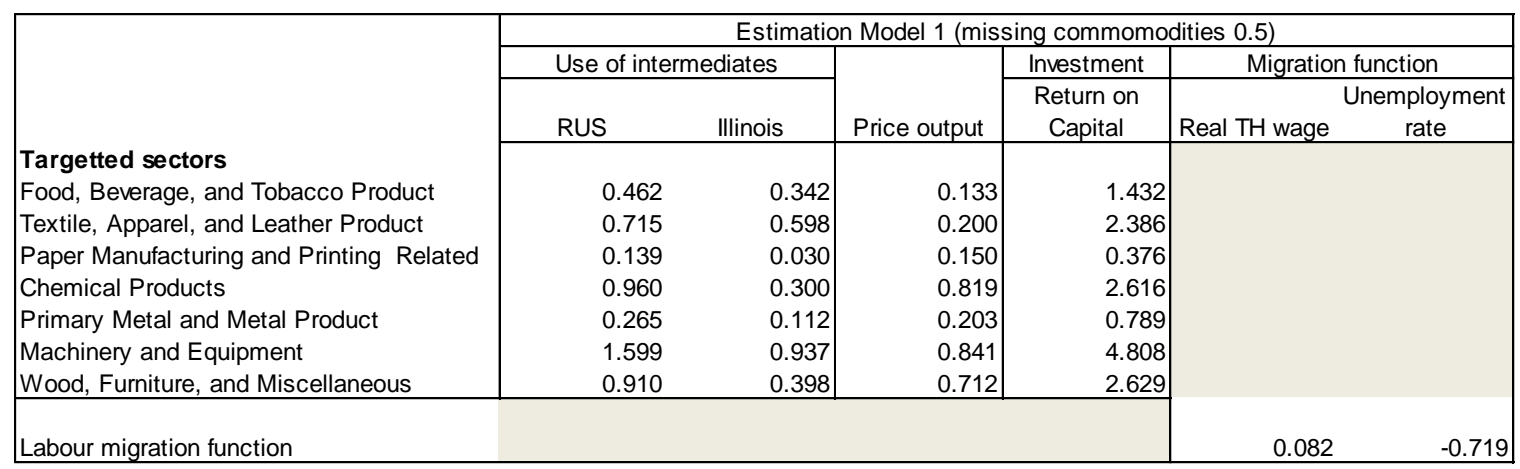

